\title{
Participation of Industry, Community and Government in Monitoring the Impact of Waste Development through the Early Warning System
}

\author{
Veronika Nugraheni Sri Lestari, Dwi Cahyono, Sri Susilowati \\ Universitas Dr. Seotomo, Surabaya \\ venugra@unitomo.ac.id
}

\begin{tabular}{ll}
\hline Article History & Received : August $9^{\text {th }} 2021$ \\
& Revision : October $13^{\text {th } 2021}$ \\
& Publication : December $30^{\text {th }} 2021$
\end{tabular}

\begin{abstract}
Abstract: In human life, it cannot be separated from the environment in which we live. Human negligence in building industry without caring the impact on environment can damage the physical and biological environment slowly and indirectly. Therefore an effort to preserve the quality of environment, especially for the environment adjacent to the settlement, is necessary and can be performed in various ways including technology utilization. The development of technologybased microcontrollers gains more popularity. Technology develops rapidly and electronic devices have become one compulsory device to be owned. Wastewater is industrial waste should be controlled prior to passing surrounding environment to avoid pollution. The concluded of this research are 1 implementation of management and monitoring carried out by industry should be led to the awareness for environmental sustainability, 2 Industrial business actor has not benefited directly from the activities of management and monitoring that have been carried out, and still considers that the obligation is a heavy burden in terms of cost, 3 Interinstitution coordination mechanism is still not clear so that each institution has not been performed their duties and functions well, 4 involvement and community awareness around the industry is relatively low.
\end{abstract}

Keywords: environment, industry building, waste water, polution

\section{INTRODUCTION}

Environment is inseparable from human life. Environment is created when human lives in and vice versa. Environmental destruction by human has increased lately by the reasons of materials utilization to produce more material. Indirectly, this action will result in erosion of the environment and threaten human survival(Hong, 2017; Star, 1999).

Human negligence in building industry without caring the impact on environment can damage the physical and biological environment slowly and indirectly( Irumba \& Mwakali, 2007; Sri Lestari et al., 2018). Therefore an effort to preserve the quality of environment, especially for the environment adjacent to the settlement, is necessary and can be performed in various ways. This includes 
preparation of local development plans to projects implementation. For example, planning the use of spatial plans for regional economic development, determination of projects to be built and time management of project implementation. Such good planning of will be able to anticipate the bad effects on surrounding environment, reduce or even prevent environmental damage. From the elaborated problem, environmental management plan for the creation of a balance between human interest and environment should be made, one of which is through technology to control environment directly(Dickey \& Shealey, 1987; Kozai et al., 2015; Lavonen et al., 2002).

The purpose of this study is to explore the importance of the role of the community, and the government in monitoring through an early warning system the impact of industrial development. Waste water from industry controlled using a $\mathrm{pH}$ sensor and informing the public through an application on an android device.

This research has the benefits include: Knowing earlier the impact of industrial development on the environment, To provide awareness from an early age on the impact of industrial development on the environment and Facilitate environmental conservation efforts as a result of industrial development.

The case study of this research was conducted in five cities, among others surabaya, gresik, lamongan, mojokerto and sidoarjo, the object area that became the target of this research is on the industrial or river waste stream channel becoming the object of industrial waste disposal.

\section{LITERATURE REVIEW}

\section{Environment}

Environment is a complex of many variables, which surrounds man as well as the living organisms. Environment includes water, air and land and the interrelation ships which exist among and between water, air and land and human beings and other living creatures such as plants, animals and micro organisms (Kalavathy, 2004). She suggested that environment consists of an inseparable whole system constituted by physical, chemical, biological, social and cultural elements, which are interlinked individually and collectively in myriad ways(Barnett \& Casper, 2001; Kalavathy, 2004; Tatalovich et al., 2006).

\section{Industry in Indonesia}

Over the last 20 years Indonesia's economic development leads to industrialization. Nearly 30,000 industries operating in Indonesia have indicated improvement. The increasing number of industrialization increase pollution resulting from industrial production processes. Pollution of water, air, land and disposal of hazardous wastes and toxic (B3) is an issue that must be faced by communities living around industrial areas(Lina, 2021; Maulidya et al., 2020). 


\section{Environmental Impact Assessment (EIA)}

Environmental Impact Assessment, which abbreviated to EIA, a reaction to environmental damage caused by increasing human activities(Awange \& Kyalo Kiema, 2013; George et al., 2020; Sousa et al., 2020). This reaction reaches extreme circumstances and cause stance against development and use of high technology. This creates image that the environmental movement is anti-development and antihigh technology and place environmental activists as opponent of development implementers and planners. Therefore many suspect that EIA is a tool to oppose and hinder development(Luttenberger et al., 2020; Zvijáková et al., 2014).

Development that does not sacrifice environment and/or damage environment is the development that takes into account the impact caused by the operation of such development. To ensure that a development can operate or feasible in terms of the environment, it is necessary to do the analysis or feasibility studies on the effects and consequences that arising from the implementation of activity / business plan.

EIA stands for environmental impact assessment. Government regulation no.27 of 1999 on environmental impact assessment states that IA is a study of major and significant impact on the decision making of a business and/ or planned activities on environment necessary for the decision making process regarding business and / or activities.

Government Regulation No.27, 1999, article 1, paragraph 1 on EIA (Environmental Impact Assessment) is a study of major and significant impacts of a business and/or planned activities on environment necessary for decision making process.

As a basis for implementing Environmental Audit in Indonesia, Decree of MoEF No.42/MoEF/11/1994 on Principles and General Guidelines for Environmental Auditing in the Appendix Decree No.41 / 94 define that:

Environmental audit is a management tool consisting of systematic, periodically documented and objective of environmental performance, system management and monitoring with the aim of facilitating control of management of effort implementation to control environmental impact and study of business feasibility or activity on legislation concerning management of environment.

Environmental audit is an effort or activity of management device conducted internally by an organization or activity as the responsibility of management and monitoring of environment. Environmental audit is not an official inspection required by legislation yet a proactive effort implemented consciously to identify environmental problems before they occur as preventative measures. 


\section{Hypothesis}

1. Development planning will have an impact on environment that is detrimental for the society.

2. Rapid development of technology will be able to help to overcome the impact of industrial development on environment.

\section{METHOD}

\section{Framework}

The first step in initiating this study is to gather data needed. The data can be obtained in the field/company. Once the data is collected, data processing is performed by using direct method, which is direct visit to the field to see the performance or condition of the development progress in Indonesia today and what changes that occur both before and after the development.

the data is obtained directly on the industrial or river waste stream channel connected to the industry and obtained from the early warning system application which is then informed directly to the community in need.

\section{Data Collection Method}

This study aims to produce data useful to provide an adequate understanding of the research object and problems faced. Therefore, the data obtained should be reliable, relevant, and can provide insight into actual situation. The method of data collection was conducted to collect data from the research object in the form of library research. This is carried out by collecting data from literature and books of reference and data that have relationship with the problems examined.

\section{RESULTS AND DISCUSSIONS \\ Negative Impact Of Industry To Environment}

We have created damage to our own ecosystem. The earth has a lot of diversity of species and natural resources. Human, or ourselves, are made up of trillions of cells. These cells undergo a process associated with life. It indicates that humans are part of nature that has a very important position. Human intellectual causes the earth verge of collapse.

Improving the living standard of Indonesian nation must be pursued through rapid economic growth by advancing development. One important element in this development is the industry construction. However, industrial activity will be followed by negative impact on the human environment.

In addition to providing positive impacts, development of Industrial zone also has negative impacts. The negative impacts are mostly related to environmental aspects. Toxin from industrial waste will worsen environmental conditions, increase the disease in humans, and damage other environmental components. 
Industrial wastewater frequently cause environmental problems such as the death of fish, poisoning humans and animals, the death of plankton, accumulated in the flesh of fish and mollusk, especially when the liquid waste contains toxins such as As, $\mathrm{CN}, \mathrm{Cr}, \mathrm{Cd}, \mathrm{Cu}, \mathrm{F}, \mathrm{Hg}, \mathrm{Pb}$, or $\mathrm{Zn}$. The accumulation of toxins in the body at intolerable concentrations can paralyze organ and kill the function of the brain.

\section{Common Symptoms Due To Industrial Waste Pollution}

\section{Short Term}

1. The river water or well water around industrial sites will be polluted. Water color changes in turbidity and smell that it cannot be used by the citizens around to bathe, wash, especially for raw materials of drinking water.

2. In terms of health, light illness like itching to severe illness of genetic defects in children and the next generation can arise.

3. The decrease in the quality of surface water around industrial areas.

4. The scarcity of fresh water especially in the dry season. While in the rainy season floods easily happens and hit many areas that cause harm due to the condition of ecosystems that have been damaged.

5. The maximum and minimum air temperatures change rapidly, even the highest temperatures in some cities such as Jakarta had reached 37 degrees Celsius.

6. The increase in the concentration of air pollution such as $\mathrm{CO}, \mathrm{NO} 2 \mathrm{r} \mathrm{S02}$, and dust

\section{Long Term}

Some diseases caused by pollution emerged years after long contamination in foodstuffs by ecologic recycle ,the example is minaimata in around 1956 in Japan. More than 100 people die or became disable due to the consumption of fish from Minamata Bay. The bay was contaminated with mercury from a plastics factory. Mercury entering human body through digestive tract can cause acute kidney damage while in children can cause Pink Disease/ Acrodynia, skin allergies and Kawasaki disease/ mucocutaneous lymph node syndrome.

Example of Environmental Pollution Case by Industry

1. In UK, before industrial revolution happened, England was filled with huge trees that possessed a lot of life to the ecosystem. The place called is now only a name. The presence of advanced technologies such as the steam engine, we human have used natural resources excessively for small thing.

2. Over the last three decades, China has transformed from impoverished farming-reliant country to the "Factory of the World," but at a high price. The widespread dumping of toxic chemicals and industrial wastewater has poisoned rivers and groundwater - and the people who rely on them (greenpeace,2018).

3. In 1992 in Semarang, a factory named Semarang Diamond Chemical (SDC) located in the Industrial Area of Semarang released waste damaging residents' pond in Tapak village. (Naufal Rafi, Pertambangan dan Perindustrian, http://rafii- 


\section{naufal.blogspot.co.id/2016/01/pertambangan-dan-perindustrian.html} accessed on 21st, March 2018)

4. In Demak area, six industries located in Genuk Industrial Area threw their waste to baboon river, causing pollution on pond to Bedono and Sriwulan.

5. Air pollution caused by steel factory around Jrakah emerging residents complain.

6. Residents also complained Abu Bakar dry spring allegedly because of groundwater taking by industries around it.

7. In Central Kalimantan, three major rivers are still contaminated with mercury as a result of gold mining along the watershed (DAS) of Barito, Kahayan, and Kapuas. The pollution exceeds the quality standards required.

8. Some mining companies throw their tailings waste into the sea (Sub Marine Tailings Disposal). First, it is Newmont Minahasa Raya (NMR) since 1996 in Minahasa, North Sulawesi, followed by PT Newmont Nusa Tenggara in Sumbawa-West Nusa Tenggara since 1999. Every day, 2,000 metric tons of tailings in paste form discharged into waters of Buyat in Minahasa and 120,000 metric ton in the Gulf Senunu, Sumbawa (Kiki Lutfillah, 2011).

All of them cause impacts that led to the decline in the quality of the environment and quality of life.

\section{Case Cause}

1. Officers' weak understanding on law enforcement, this can happen to police and courts regarding environmental regulations.

2. Weak law enforcement in Indonesia regarding environmental pollution.

3. The absence of decisive action from the government to prohibit the discharge of tailings into Indonesia sea. Other countries have prohibit the method of tailings disposal. Even Canada, a country used this method for the first time no longer uses the STD method considering the very long recovery to 150 years. Meanwhile Indonesia grants permission for the practice of the method of tailings disposal with this STD.

4. The state closes people's access to information related to the industry including industrial waste.

5. The exclusion of the public in maximum level in environmental management, it appears that environment is only concern for government while company does not become public affairs as a party that uses a lot of environmental services.

\section{Knowledge and understanding of industrial development impact.}

It is mandatory for all of us to know the relationship between the type of environment. This is very important in order to tackle environmental issues in an integrated and complete way. Law enforcement officers also need to be given the knowledge as much as possible about the problem of environmental pollution.

The government must monitor industrial activities and disposal of wastes like on figure 1 between society and industry also between industry and Government had cooperation. Industry players must prevent environmental pollution by implementing clean technologies, installing pollution prevention, recycling process 
and most importantly, must performing waste processing to eliminate material contamination or at least minimize contamination of materials to the threshold.

One of the methods to monitor the existing activities using an early warning system that capable of informing industrial waste disposal conditions through river or river ducts directly to community.

In addition, it is necessary to study or conduct a study on the impact of specific industrial wastes (according to the type of industry) to the environment and to find methods or the appropriate technology for the prevention of the problem.

In addition to government and industry, society should be keen to respond to environmental problems caused by industrial activities. Society cannot fully submit this issue to the government and industry players. Addressing this issue is absolutely necessary, especially for people living around industrial areas. The impact of the discharge of industrial activities is very complex. Basically industrial waste will pollute the air, water, and soil. Dirty and polluted air will damage the olfactory and lungs.

Water pollution will damage aquatic and certainly will disturb the existence and availability of clean water sources. Pollution of soil, besides disturbing the soil fertility and anything that lives and grows on it will ultimately disrupt and contaminate the groundwater.

Based on data from Environment Agency of East Java Province, year 2016, the cause of high pollution of waste both solid and liquid waste is due to the increase in volume. Where the higher the volume and the waste discharges generated, the higher the pollution load. Waste volume may increase if there is an increase in production capacity, increased population, ineffective tool or process of activity or human error. The volume of solid waste at the source of movable and immovable sources can be seen there are graphs as follows :

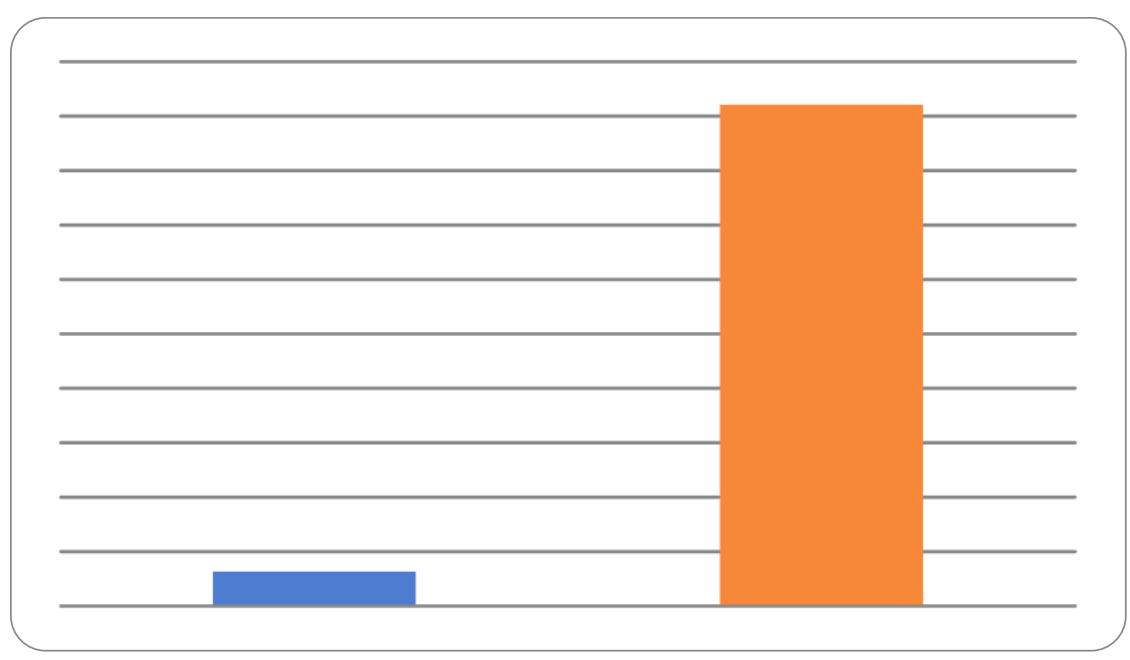

Figure 1 Solid Waste Volume on Pollution Source (source: Environment Agency of East Java Province, year 2016) 
According to figure 1 that the volume of customary waste is generated by an unstable pollutant of $921.101 \mathrm{M}^{3} /$ day, Moving sources include tourism activities, office buildings, mosques while moving sources include activities in terminals, stations, and ports. The volume of solid, waste at a moving pension source is 63,230 $\mathrm{m}^{3} /$ day.

The fact that the water quality index in East Java is 52.51 in 2015 to 50.75 in 2016 or in the "Very Less" status. The water quality index in the national strategic river area of Brantas River Region in 2016 was 47.68, down from the previous year at 49.17. While quality in the Bengawan Solo river area of 48.75. These two national strategic interests are in the "Alert" condition. Existing condition of river water quality in East Java showed BOD concentration of 87,4\%, Total Coli 49\%, Coli stool $55,98 \%$, COD equal to $7,2 \%$, TSS at $65 \%$ at monitored location tended to far exceed quality standard class II river water based on integrated water quality monitoring conducted by BLH East Java Province, Perum Jasa Tirta, Irrigation Service of East Java Province and Regency / City BLH.

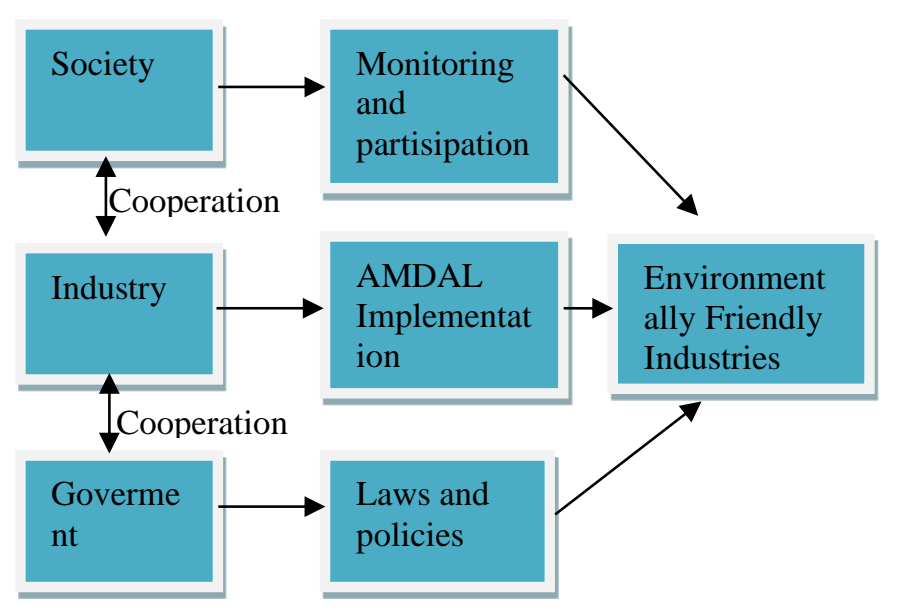

Figure 2. Environmentally Friendly Industries diagram

according to the above statement and based on image 2 monitoring becomes an important keyword to minimize the impact of industrial waste as has been done by the Environment Agency of East Java Province has conducted recapitulation of the number of industries that have been supervised in the period January to December 2016 is as many as 159 industries and / or business activities others in East Java, consist of 13 hospitals, 39 hotels / apartments, 3 tourist attractions and 104 industries spread over several districts / municipalities East Java, can be shown with the following graph (figure 3) 


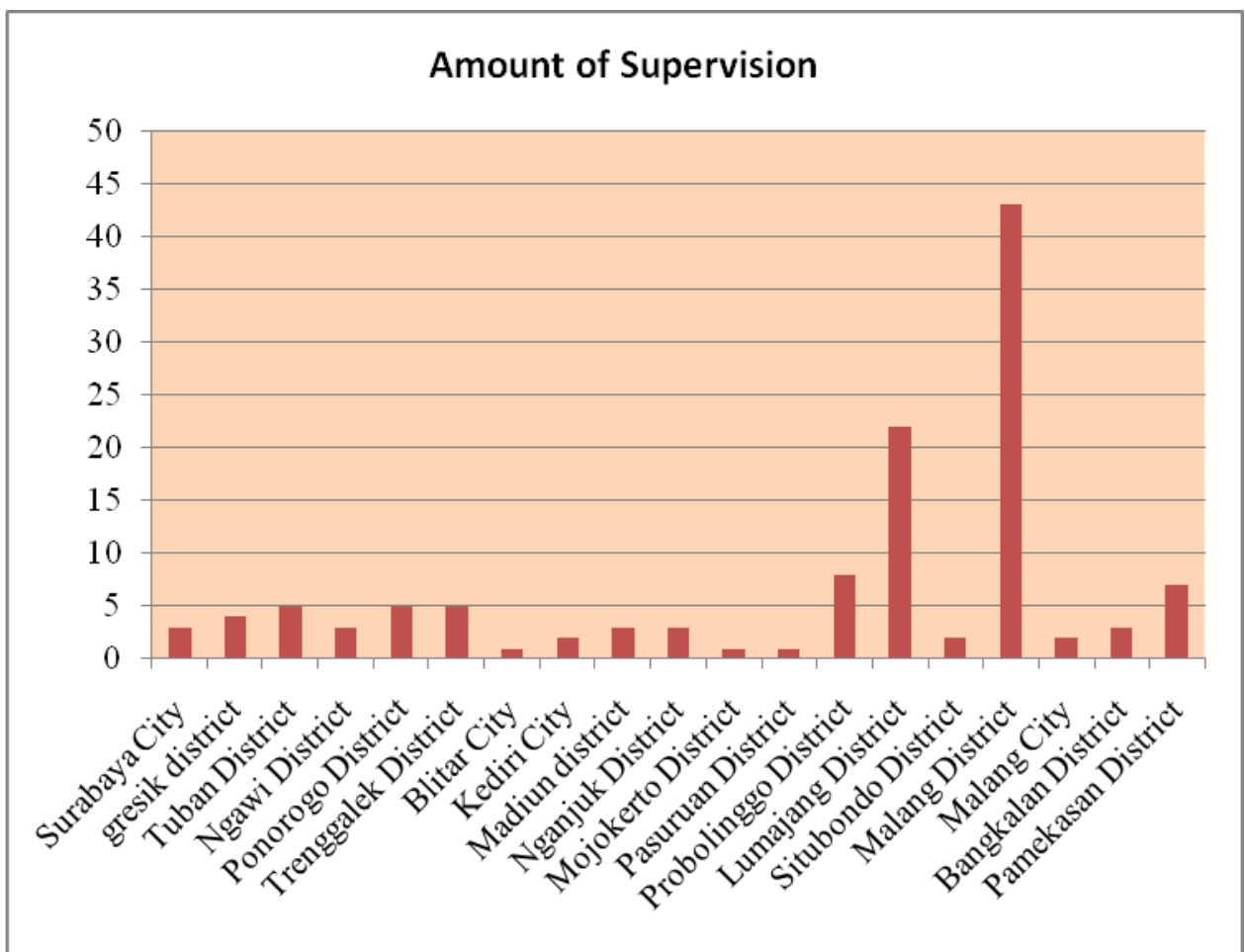

Figure 3. Supervision of Industry / Other Business Activities in East Java Year 2016 (source: Environment Agency of East Java Province, year 2016)

From the graph shown in figure 3 there is a PROPER Activity (Corporate Performance Rating Program in Environmental Management) is an incentive / disincentive instrument in accordance with Article 42 of Law No. 4/1999. 32 of 2009 on Environmental Protection and Management. where according to the report of the environmental agency in 2016 is the proper level where there are 188 participants PROPER value tendency achievement level of obedience in general there is an increase in corporate compliance rate of $11 \%$ in 2016 as shown in table 1 and figure 4 below :

Table 1 The tendency of achieving a general level of obedience (source: Environment Agency of East Java Province, year 2016)

\begin{tabular}{|c|c|c|}
\hline Period & $\begin{array}{l}\text { Obedient } \\
\text { (\%) }\end{array}$ & $\begin{array}{l}\text { Disobedient } \\
(\%)\end{array}$ \\
\hline 2009 & 61.8 & 38.2 \\
\hline 2010 & 60.95 & 39.05 \\
\hline 2011 & 58.5 & 41.5 \\
\hline
\end{tabular}




\begin{tabular}{rrr}
2012 & 80.82 & 19.18 \\
2013 & 79.43 & 20.57 \\
2014 & 82.86 & 17.14 \\
2015 & 82.8 & 17.2 \\
2016 & 93.26 & 6.74 \\
\hline
\end{tabular}

Table 1 above can be formulated to graphic as shown in figure 4 below

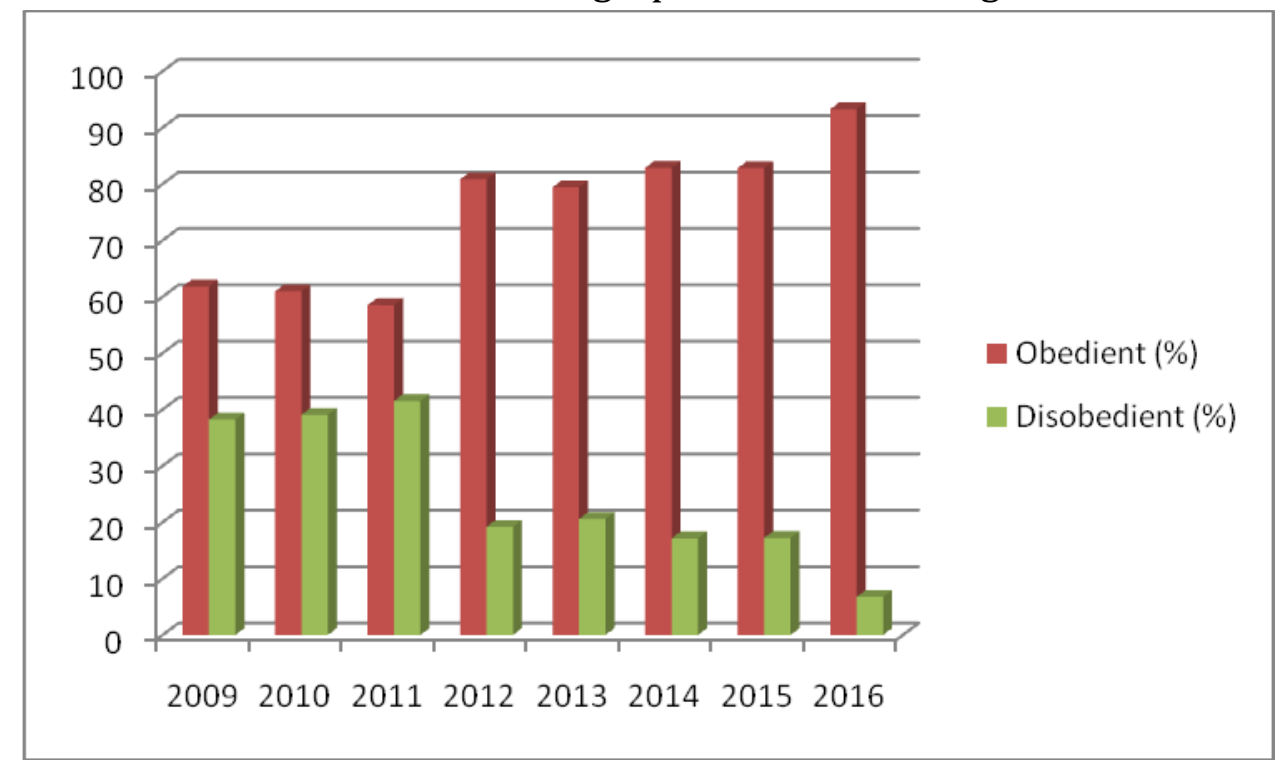

Figure 4. graphict for The tendency of achieving a general level of obedience

(source: Environment Agency of East Java Province, year 2016)

\section{CONCLUSION}

Based on the results of the assessment of the impact of industry on the environment, it can be concluded that:

1. Implementation of management and monitoring carried out by industry should be led to the awareness for environmental sustainability.

2. Industrial business actor has not benefited directly from the activities of management and monitoring that have been carried out, and still considers that the obligation is a heavy burden in terms of cost.

3. Inter-institution coordination mechanism is still not clear so that each institution has not been performed their duties and functions well

4. involvement and public awareness around the industry is relatively low.

5. Tendency achievement level of obedience in general there is an increase in corporate compliance rate of $11 \%$ in 2016. 


\section{REFERENCES}

A Study of the Awareness of Property Managers and Other Built Environment Professionals on Sustainable Buildings in Kaduna Nigeria. (2016). International Journal of Research in Chemical, Metallurgical and Civil Engineering. https://doi.org/10.15242/ijrcmce.iae0316421

Awange, J. L., \& Kyalo Kiema, J. B. (2013). Environmental Impact Assessment. In Environmental Science and Engineering. https://doi.org/10.1007/978-3-642-340857_28

Barnett, E., \& Casper, M. (2001). A definition of"social environment" [1]. In American Journal of Public Health. https://doi.org/10.2105/ajph.91.3.465a

Dickey, R., \& Shealey, S. H. (1987). Using technology to control the environment. The American Journal of Occupational Therapy. : Official Publication of the American Occupational Therapy Association. https://doi.org/10.5014/ajot.41.11.717

George, T. E., Karatu, K., \& Edward, A. (2020). An evaluation of the environmental impact assessment practice in Uganda: challenges and opportunities for achieving sustainable development. Heliyon. https://doi.org/10.1016/j.heliyon.2020.e04758

Hong, P. (2017). The Literature Review on Compensation System Design. Modern Economy. https://doi.org/10.4236/me.2017.89077

Irumba, R., \& Mwakali, J. (2007). Ethics in construction: Examples from Uganda. Proceedings of CIB World Building Congress,.

Kalavathy. (2004). Definition-Environment. Archives of Disease in Childhood.

Kozai, T., Kubota, C., Takagaki, M., \& Maruo, T. (2015). Greenhouse environment control technologies for improving the sustainability of food production. Acta Horticulturae. https://doi.org/10.17660/ActaHortic.2015.1107.1

Lavonen, J., Meisalo, V., \& Lattu, M. (2002). Collaborative problem solving in a control technology learning environment, a pilot study. International Journal of Technology and Design Education. https://doi.org/10.1023/A:1015261004362

Lina, N. (2021). TOXIC AND HAZARDOUS WASTE (B3) MANAGEMENT AT PT. PAL INDONESIA (PERSERO). The Indonesian Journal of Public Health. https://doi.org/10.20473/ijph.v16i3.2021.449-460

Luttenberger, L. R., Matić, J., Mihelić, D., \& Mandić, N. (2020). Environmental impact assessment procedures for projects in marine environment - evaluation analysis. Pomorstvo. https://doi.org/10.31217/p.34.1.8

Maulidya, A. D., Fitriah, M. N., \& Chandra, E. Y. (2020). The Urgency of Indonesia to Control Imports of Non- Hazardous and Toxic Waste (B3) in 2019. Globa Local Interactions: Journal of International Relations.

Sousa, P., Gomes, D., \& Formigo, N. (2020). Ecosystem services in environmental impact assessment. Energy Reports. https://doi.org/10.1016/j.egyr.2019.09.009

Sri Lestari, V. N., Cahyono, D., \& Susilowati, S. (2018). Designing Early Warning System for The Impact of Industrial Development Waste by Using $\mathrm{pH}$ Control System. International Journal of Engineering \& Technology. https://doi.org/10.14419/ijet.v7i2.11581

Star, S. L. (1999). The ethnography of infrastructure. American Behavioral Scientist. https://doi.org/10.1177/00027649921955326

Tatalovich, Z., Wilson, J. P., Milam, J. E., Jerrett, M. L. B., \& McConnell, R. (2006). Competing definitions of contextual environments. International Journal of Health Geographics. https://doi.org/10.1186/1476-072X-5-55 
Zvijáková, L., Zeleňáková, M., \& Purcz, P. (2014). Evaluation of environmental impact assessment effectiveness in Slovakia. Impact Assessment and Project Appraisal. https://doi.org/10.1080/14615517.2014.893124 